\title{
Song as Event: On Intermediality and the Auditory
}

Erik Wallrup

\section{Abstract}

The background of intermedial studies related to language and tone or sound, reaching all the way back to the comparative literature of the I950s, can be discerned still today in the tendency to focus upon matters of signification and treating music as a medium of communication (indeed as a semiotic system). Through a critique of the typologies or models of intermedial relations afforded by Werner Wolf and Lars Elleström, followed by a discussion on an auditory model presented by Calvin Scott, this article suggests that song should be understood as an event, a both linguistic and musical event that takes place in time and in sound, where the semiotic character of music cannot be taken at face value. With the fourteenth song from Arnold Schoenberg's I5 Gedichte aus Das Buch der hängenden Gärten von Stefan George op. I 5 and its George poem as touchstones, the different typologies and models are scrutinized, ending with the suggestion that a promising intermedial investigation would be the elucidation of the differences and similarities between the world of the song and the world of the poem. In the earlier case, this world is primary to the ensuing sign relations as well as the relation between the basic media that are parts the qualified medium song.

How to cite this book chapter:

Wallrup, Erik. "Song as Event: On Intermediality and the Auditory." In The Power of the In-Between: Intermediality as a Tool for Aesthetic Analysis and Critical Reflection, edited by Sonya Petersson, Christer Johansson, Magdalena Holdar, and Sara Callahan, 349-374. Stockholm: Stockholm University Press, 2018. DOI: https://doi.org/IO.I6993/baq.n. License: CC-BY. 


\section{Introduction: Schoenberg and George as Touchstones}

One of the most intriguing questions concerning musical modernism is why Arnold Schoenberg in 1907 turned to Stefan George (or, perhaps, George's poetry chose Schoenberg) in his urge to free himself from the restrictions of tonality. He prided himself of being a song composer who did not with care read the poems to be set: "I had composed many of my songs straight to the end without troubling myself in the slightest about the continuation of the poetic events." "The act of composition, so he maintains, took place only with the impact from the first sounds of the poems. At the time deeply involved with asymmetric composition (or, "musical prose," as he would term it later ${ }^{2}$ ), he was seemingly at odds with the strict verses of so much of George's poetry. Schoenberg loosened the grip of meter, rhyme, and assonance, decomposing all those linguistic traits that are often hailed as "musical" characteristics of Stefan George's poems. His treatment of the texts was the composer's version of how, with George Steiner's famous phrase, the "contract between word and world" can be broken, ${ }^{3}$ here, however, understood as the contract between word and music in the German Lied. One should also bear in mind that it was precisely George who brought Hugo von Hofmannsthal into the distress that lead to the writing of the Lord Chandos letter, ${ }^{4}$ that painful report on the separation between language and world with silence as its ultimate consequence.

This breach of contract is certainly not an affair for music historians only. It has an impact on intermedial studies as well,

I Arnold Schoenberg, "The Relationship to the Text," in Style and Idea (Berkeley: University of California Press, I984), I44.

2 Arnold Schoenberg, "Brahms the Progressive," in Style and Idea, 4I 5. An authoritative account of the term can be found in Carl Dahlhaus, "Musikalische Prosa," in Gesammelte Schriften, vol. 8, 20. Jahrhundert (Laaber: Laaber, 2005).

3 George Steiner, Real Presences: Is There Anything in What We Say (London: Faber and Faber, I989), 8. Later (93) he writes: "It is this break of the covenant between word and world which constitutes one of the very few genuine revolutions of spirit in Western history and which defines modernity itself." (Italics in the original.)

4 Hugo von Hofmannsthal, "Ein Brief," in Gesammelte Werke: Erzählungen, Erfundene Gespräche und Briefe, Reisen (Frankfurt: Fischer, I979), 46I-472. 
not at least since it calls for reflection upon the history and prehistory of the discipline. If we turn back to the emergence of the interdisciplinary study of literature and music from comparative literature, with Calvin S. Brown's Music and Literature: A Comparison of the Arts (1948) as a kind of starting point for what was to become interart studies and later intermedial studies related to language and tone or sound, then we can see that the possible connections between music and text highlighted by Brown-primarily concerning form but also the imitating "literal setting" and the suggestive "dramatic setting" - fall outside the field opened up by Schoenberg. ${ }^{5}$ However, precisely as Jørgen Bruhn suggests in an introduction to the discipline of intermedial studies, this kind of interart-related question is not a very promising one for the understanding of intermedial relations, ${ }^{6}$ even if there is many an example of studies of that vein still existing in the field.

An important branch of intermedial studies, including investigations of the relation between music and language, has had semiotics as its theoretical underpinning. In a most general formulation, medium is here understood as something that diffuses information or signs, and that might explain why musicology has responded reluctantly to intermediality and why there are not that many musicologists who have turned to intermedial studies. ${ }^{7}$ It is true that music can be a sign when incorporated in film (only the slightest touch of non-Western scales signifies something exotic and foreign in Hollywood productions), intended musical intertextuality can be found in Medieval music already (perhaps in the music of the Antiquity, too, but we do not know much about the actual compositions), and of course there is musical semiotics (of different kinds). However, the ordinary musicologist

5 Calvin S. Brown, Music and Literature: A Comparison of the Arts (Athens: The University of Georgia Press, I949). The formal aspects dominate his discussion, on "literal" and "dramatic" setting, see 53-86.

${ }^{6}$ Jørgen Bruhn, "Intermedialitet: Framtidens humanistiska disciplin?," Tidskrift för litteraturvetenskap 38: I (2008): 2I-38.

7 Mats Arvidson points out this reluctance, with Sweden as his example, in the article "Music and Musicology in the Light of Intermediality and Intermedial Studies," STM-Online I 5 (20I2), unpaginated. 
looks with some suspicion at these different fields, taking them for being perhaps interesting, but in one way or another missing the point of music.

Exactly this suspicion leads back to Arnold Schoenberg, who did not only reflect upon his own music when he said that to him reading the text of a song is of no importance for the understanding of the actual song. He had then the texts to Schubert's Lieder in mind: "when I had read the poems it became clear to me that I had gained absolutely nothing for the understanding of the songs thereby, since the poems do not make it necessary for me to change my conception of the musical interpretation in the slightest degree." ${ }^{8}$ Then, it seems that there is hardly any reason at all for a composer to include a text in a composition, but that is not what Schoenberg means. Later he writes: "I had completely understood the Schubert songs, together with their poems, from the music alone, and the poems of Stefan George from their sound alone, with a perfection that by analysis and synthesis could hardly have been attained, but certainly not surpassed." 9

It is exactly here a critical intermedial scholar should intrude, saying that the most interesting thing to know is precisely the relationship_-parallels and analogies, but more interestingly the differences-between the poem as poem and the poem in the song. The words in the poem and the words in the song are often more or less identical but as we shall see they are not one and the same. ${ }^{10}$ Schoenberg's own George settings show that most emphatically. Accordingly, the intermedial relation to be focused upon here is the one between a poem and a song that is the setting of that same poem. Two media, poem and song, are put forth and are being interrelated to each other.

What I would like to show theoretically in this article is that in some of the most influential thoughts about intermediality and songs, music is mistaken for a semiotic system, which leads to a

8 Schoenberg, "The Relationship to the Text," I42.

9 Schoenberg, "The Relationship to the Text," I 44 .

to Yet, sometimes the composer has changed the text, deliberately or by mistake. Other deviances, quite common, are reiteration of words or whole verses due to structural or expressive reasons and the neglect of following the periods of the verses (which otherwise give the poem a sense of order both visually and acoustically_-when read aloud or with the inner voice). 
biased view on songs in general. Both Werner Wolf's highly diversified typology and Lars Elleström's elaborated reflections, the latter relying on Peircean semiotics, are to be discussed from this perspective. That does not lead to a dismissal of their thinking. Wolf's many distinctions are often useful, and Elleström's broad understanding of media gives insights into subtle intermedial relations, but the main problem concerning music and semiotics still remains. As I will explain, music should not be understood as a semiotic system, even if semiotics with no doubt has a lot to say about certain perspectives on music. I shall argue that a song ought to be understood as an event, a both linguistic and musical event that takes place in time and in sound, where the semiotic character of music cannot be taken at face value. Doing so, references are made to an auditory-oriented model of intermediality in song, presented by Calvin Scott, but his suggestion is also criticized for its shortcomings.

The intent is, therefore, to elaborate conceptually both positive and negative interrelations between poem and song. This is carried out through the introduction of concepts that may seem to be alien to an intermedial context-such as "event," the "world" of an artwork, and the "tone" of a text-but such that can overcome the semiotic bias, which hinders the understanding of auditory-based intermediality. I will more than once come back to Schoenberg and his George settings, this in order to counteract the tendency in much theoretical writing to lose contact with the concrete, but also due to the fact that Schoenberg's songs from the period I907-09 put a pressure on the stable and unproblematic relation between the poem as it can be read on paper and the same words as a constituent part of a song. In short, these songs are exemplary because of the liberties Schoenberg allows himself.

\section{The Semiotic Overstatement}

Even if Werner Wolf is totally aware of the fact that the background of intermedial studies in comparative literature has had repercussions upon the field, ${ }^{11}$ his view on the relation between

i Cf. Werner Wolf, “Intermedialität als neues Paradigma der Literaturwissenschaft? Plädoyer für eine literaturzentrierte Erforschung von 
music and language is determined by his way of seeing media as belonging to the sphere of communication and the work to be investigated defined by its signification or the semiotic structure/ complex of the work. ${ }^{12}$ Having started within the frames of interart studies, where the object of research is first of all the multi- or plurimedial artwork itself, he has broadened the scope through allowing relations outside the work of art. What he calls "intracompositional intermediality" (or intermediality in the narrow sense) can be supplemented by "extracompositional intermediality" (such as transmediality and intermedial transposition). ${ }^{13}$

An obvious problem is, however, that Wolf recognizes that "music cannot unambiguously refer to a reality outside itself, let alone to such abstract concepts as a different medium" ${ }^{14}$ at the same time as he stresses the semiotic character of the work. Here, the point to be made is not that there is nothing such as an "unambiguous reference" between a sign and reality; instead, the problem lies in the circumstance that music is held to be both semiotic and without reference (neither to reality, nor to any other semiotic system outside itself, whereas the self-reference is unclear). Music would then be semiotic but without signs referring to other signs or to reality. As already suggested, music may have

Grenzüberschreitungen zwischen Wortkunst und anderen Medien am Beispiel von Virginia Woolfs 'The String Quartet," Arbeiten aus Anglistik und Amerikanistik 2I:I (I996): 85-II 6 and "Intermediality Revisited," in Essays in Honor of Steven Paul Scher on Cultural Identity and the Musical Stage, ed. Suzanne M. Lodato, Suzanne Aspden, and Walter Bernhart, Word and Music Studies (Amsterdam: Rodopi, 2002), $2 \mathrm{I}$.

${ }^{12}$ Wolf defines "intermediality" in the narrow sense as "a direct or indirect participation of more than one medium of communication in the signification and/or semiotic structure of a work or semiotic complex, an involvement that must be verifiable within this semiotic entity." Wolf, "Intermediality Revisited," I 7.

${ }_{3}$ Wolf's most developed description of "intracompositional intermediality" can be found in the chapter "'Intermediality': definition, typology, related terms" in his The Musicalization of Fiction: A Study in the Theory and History of Intermediality (Amsterdam: Rodopi, 1999), 35-50. "Extracompositional intermediality" is introduced in the article "Intermediality Revisited."

I4 Wolf, "Intermediality Revisited," 24. 
a semiotic character, most obvious in film and opera, often clear in programme music, but the major characteristics of music is not dependent on semiotic relations.

When we turn to Lars Elleström's intricate model for intermedial relations, the main problem concerning song and music is still there. Elleström asserts that song (or, more specifically, the pop song) is a qualified medium combining and integrating two basic media, where a sounding text is combined with organized non-verbal sound. Both basic media have a common material interface, but the semiotic modalities of theirs differ: meaning in the sounding text is said to be determined first of all in a decoding of conventional signs whereas the organized non-verbal sound is mainly interpreted in terms of iconicity. ${ }^{15}$

As far as I know, Elleström has not developed a more detailed account for the iconicity of music, even if he touches upon the theme in an article on iconicity and miming. ${ }^{16}$ However, in an anthology, which happens to be co-edited by Elleström, we find an article by the Swiss semiotic scholar Costatino Maeder, who describes three different iconic strategies that tie music to the linguistic arts when combined in opera and oratorio. Of course, these strategies do not have to be totally in accord with Elleström's views, but they lead in a direction that affords us with a better understanding of the semiotic character-and possibilities-music may have from time to time. Maeder says that music is a "semiotic system that differs drastically from the functioning of human language," ${ }^{17}$ but when he describes the three main strategies, he is quite close to the sounding elements of language. Firstly, "music mimes the prosody of human speech (rhythm, stress, and intonation)," secondly, it "mimes linguistic and psychological behaviour of human beings

is Cf. Lars Elleström, "The Modalities of Media: A Model for Understanding Intermedial Relations," in Media Borders, Multimodality and Intermediality, ed. Lars Elleström (London: Palgrave Macmillan, 2010), 29.

${ }^{16}$ Lars Elleström, "Iconicity as Meaning Miming Meaning and Meaning Miming Form,” in Signergy, ed. Jac Conradie et al. (Philadelphia: John Benjamins, 2010), 73-100.

${ }^{17}$ Costantino Maeder, "Opera, Oratorio, and Iconic Strategies," in Iconic Investigations, eds. Lars Elleström, Olga Fischer, and Christina Ljungberg (Philadelphia: John Benjamins, 20I3), 275. 
under pressure," and thirdly, it "mimes and models communicative processes; for example, dialogue, argumentation." ${ }^{88}$ Of these, the first two strategies are foremost bound to imagic iconicity, and the third one to diagrammatic iconicity.

Maeder's approach allows him to not get stuck on the question of whether music alone, that is, instrumental music without a programme, has any iconic characteristics or not (he does, however, describe different views on the matter, from Eduard Hanslick's and Carl Dahlhaus's notions of "absolute music" to Jean-Jacques Nattiez's declaration that music has at least a weak capacity of transferring propositional content ${ }^{19}$ ). Yet, what he has to say about iconicity in opera and oratorio has a lot to do with the problem put forward by me. In the context of a scene in an opera or an oratorio, music may mime prosody, behavior, and verbal structure. It is also true that these elements have a close relation to the characters on a scene (in an oratorio, we also most often find characters). However, much of the musical activity in the orchestra usually does not have something to do with how the characters speak, behave and communicate directly. The same counts for the short "scene" of a song. We can of course find a poetic I or a persona of the poem, but the relevance of Maeder's iconic strategies are limited when it comes to that poem set to music and then especially concerning the accompaniment.

\section{The Formalistic Overstatement}

What kind of alternatives do we have to an iconic foundation of music's relation to its text in songs? In "Ich löse mich in tönen...": Zur Intermedialität bei Stefan George und der Zweiten Wiener Schule, Calvin Scott tries to free the conception of intermediality from both its background in literary studies and the visual dominance in much writing in the field. The reason for him to carry out his investigations is precisely Stefan George's poetry, which has been set to music by composers such as Arnold Schoenberg, Anton Webern, and Alban Berg, but which in itself stands in

\footnotetext{
I8 Maeder, “Opera, Oratorio, and Iconic Strategies," 275-276.

19 Cf. Maeder, “Opera, Oratorio, and Iconic Strategies," 277.
} 
intermedial relations beyond referentiality. One of the aspects is visual, due to George's awareness of the designing of his literary production, realizing a new sans-serif font for his books and collaborating with the painter and designer Melchior Lechtor, who did the decoration for a series of George's books. However, even if Lechtor's work made George's collections of poems into artworks in their own right, being opulent expressions of the art noveau style, Scott is able to show that George's typography and even orthography give support to the auditory aspects of the poems. The typographic design estranges the reader from the words, ${ }^{2 \circ}$ whereas the spelling has a tendency to come as close as possible to spoken words (for instance is "-tzt" in " $z u l e t z t$ " reduced to "- $z t$," non-pronounced letters such as " $b$ " in "wohl" are omitted, and long vowels such as "-o-" in "los" are written with double letters, "loos"). ${ }^{21}$ Both the physical books, being highly elaborated art objects, and the visual characteristics of their typography point at Stefan George's urge to make his poetic words into a cult. The readings within the George circle were of vital importance for his poetic activities, and they should be understood in terms of events, taking place in time, within a space and in a community. George's texts can therefore be seen as scores for performances. When set to music, this circumstance does not change.

Calvin Scott underscores that the aural phenomenon is always temporal and spatial, and if such a thing as a song is to be investigated, then it must be seen as an event and a process. Distancing himself expressly from the conception of intermediality to be found in Wolf's writings, Scott suggests the following:

A concept of intermediality, which should answer to something as fugitive-unstable as acoustic-sounding phenomena, demands first of all the discharge of the idea that matters of "intermedial" interrelationships should be about the presence of available and

${ }_{20}$ Scott refers to the Germanist Armin Schäfer, who has shown that the typography obstructs word identification: “'Gelesen’ werden lediglich Buchstabengruppen statt Wörter." Calvin Scott, "Ich löse mich in tönen...”: Zur Intermedialität bei Stefan George und der Zweiten Wiener Schule (Berlin: Frank \& Timme, 2007), 49, n. I I9.

${ }^{21}$ Scott, "Ich löse mich in tönen...," 48. 
concrete artefacts, in which the "establishment of contact" between "media of communication" or a "conceptual togetherness" of "medial quotes and elements" are at hand statically. "Intermediality" denotes from now on a phenomenon that "takes place" in an utterly temporary, dynamical way. ${ }^{22}$

Scott's criticism is probably directed at earlier stages of the development of intermedial studies, when the transformation of a drama or a novel into a film or an opera was a typical theme for research, but he actually wants to re-establish some of the earliest formulations of intermediality, namely by the scholar of Slavic studies Aage Hansen-Löve, who in his investigations of the relation between literature and pictorial art suggested a formalistic understanding of the intermedial correlation between these forms of art. The correlations were said to take place in between, in an oscillation between the preconceived art forms. ${ }^{23}$

It is, however, through turning to the sociologist Niklas Luhmann that Scott finds his solution. In Luhmann's definition of "medium," the relation to "form" is of vital importance: "A medium consists of loosely coupled elements, whereas a form brings these same elements into a tight coupling." ${ }^{24}$ From this follows

${ }_{22}$ Scott, "Ich löse mich in tönen...," 27 (my trans.): "Ein Intermedialitätskonzept, das etwas so Flüchtig-Instabilen wie dem Akustisch-Lautlichen gerecht werden will, erzwingt zunächst die Verabschiedung der Vorstellung, es würde sich bei der Frage nach 'intermedialen' Wechselbeziehungen um jederzeit verfügbare und handfeste 'Artefakte' handeln, in denen eine 'Kontaktaufnahme' von 'Kommunikationsmedien' oder ein 'konzeptuelles Miteinander' von 'medialen Zitaten und Elementen' statisch vorliegt. 'Intermedialität' bezeichnet nunmehr ein äußerst temporäres, dynamisch 'stattfindendes' Phänomen.”

${ }_{23}$ Scott refers to an article that Aage Hansen-Löve published for the first time as "Intermedialität und Intertextualität: Probleme der Korrelation von Wort- und Bildkonst - Am Beispiel der russischen Moderne," in Dialog der Texte: Hamburger Kolloquium zur Intertextualität, Wiener slawistischer Almanach, Sonderband II, eds. Wolf Schmid and WolfDieter Stempel (Wien: Gesellschaft zur Förderung slawistischer Studien, I983), 29I-360.

${ }^{24}$ Niklas Luhmann, Die Gesellschaft der Gesellschaft (Frankfurt: Suhrkamp, I997), I98 (my trans.): “Ein Medium besteht in lose gekoppelten Elementen, eine Form fügt dieselben Elemente dagegen zu strikter Kopplung zusammen." Quoted by Scott, "Ich löse mich in tönen...," 30. 
that the loosely coupled elements are tightly coupled by the medium in an event: the form is not everlasting but takes place in time. Further, there is an hierarchic relation where that which is a medium in one instance (for example sound) is tightly coupled by the form of words, whereas these words in the medium of language is arranged in the form of sentences, and these sentences in their turn can be elements within the medium of literature. ${ }^{25}$ Scott's conclusion, when it comes to the relation between different media such as language and music, is that it would be possible to see how the media at some point are coupled to each other through having elements in common, whereas they in other instances may lack such joints. Since, according to Scott, language is characterized by having a reference to the outer world whereas music is self-referential, the intermedial relation between language and music is restricted to those formal arrangements that are supposed to exclude meaning. Forms such as metrical schemes and specific poetic forms (sonnet, ottava rima, etc.), as well as rhythmical figurations and melodic phrasing can be mirrored in the different media.

Let us see, then, what this means when Scott reaches the concrete works. I shall turn to a George setting by Schoenberg that has the advantage of having been richly commented upon by scholars of different strands, the fourteenth song of 15 Gedichte aus Das Buch der hängenden Gärten von Stefan George op. I 5 (Figure I). ${ }^{26}$ The short lines, the rich but often not symmetric rhymes, but especially the stern meter and a choice of words giving prominence to the vowels "-au-" and "-i-" are characteristics that come to mind.

${ }_{25}$ Cf. Niklas Luhmann, Die Kunst der Gesellschaft (Frankfurt: Suhrkamp, I995) quoted and commented by Scott, "Ich löse mich in tönen...," 32.

26 The poem reads in toto: "Sprich nicht immer / Von dem laub • / Windes $\mathrm{raub} \cdot /$ Vom zerschellen / Reife quitten · Von den tritten / Der vernichter / Spät im jahr · / Von dem zittern / Der libellen / In gewittern / Und der lichter / Deren flimmer / Wandelbar.” Stefan George, Werke: Ausgabe in zwei Bänden (Stuttgart: Klett-Cotta, I984), ro9. Schoenberg has normalized the text and made it into prose. Cf. Arnold Schoenberg, I5 Gedichte aus Das Buch der hängenden Gärten von Stefan George (Wien: Universal, I908-09), 32: "Sprich nicht immer von dem Laub, Windesraub; vom Zerschellen reifer Quitten, von den Tritten der Vernichter spät im Jahr. Von dem Zittern der Libellen in Gewittern, und der Lichter, deren Flimmer wandelbar." 
30

XIV
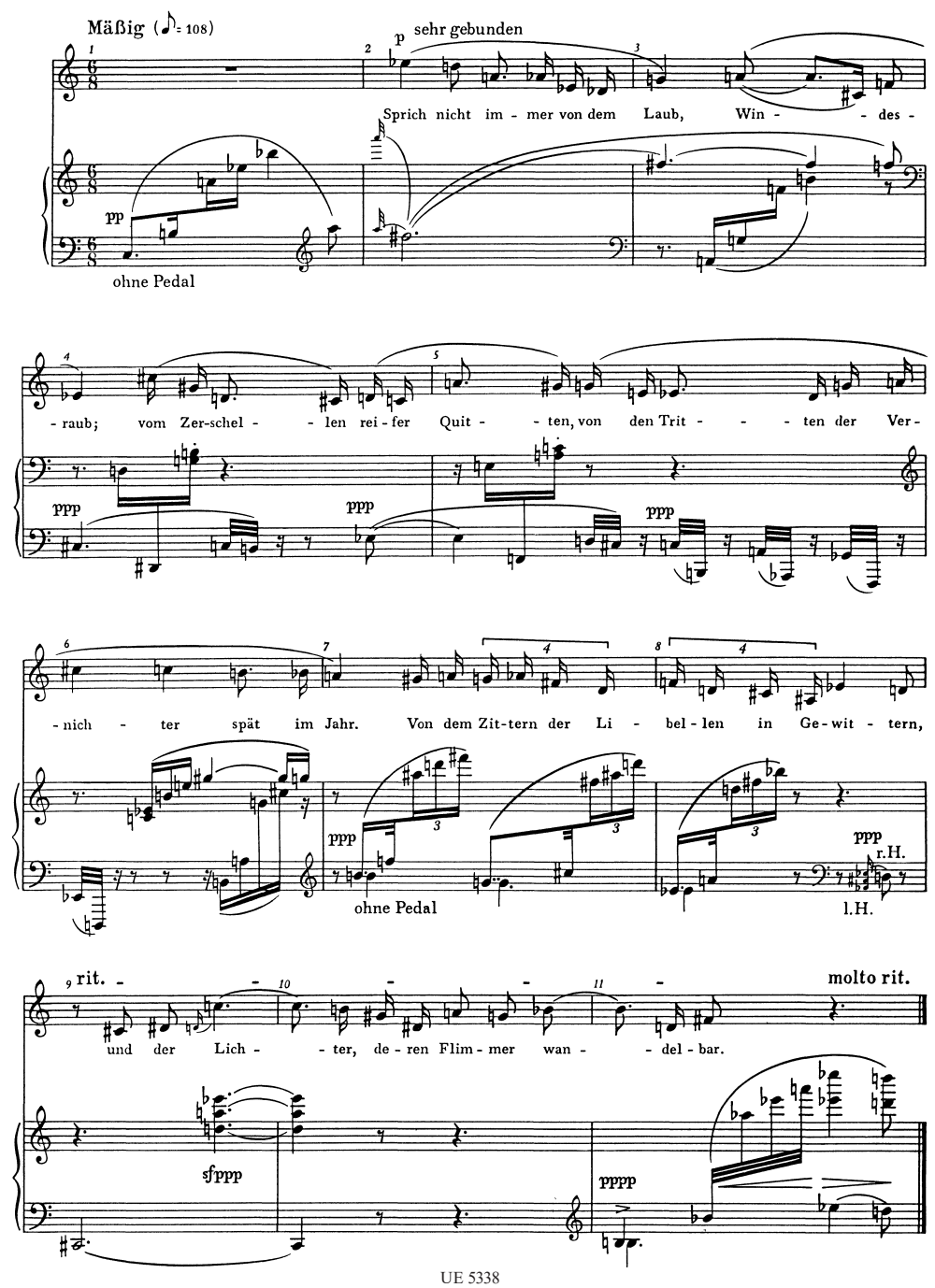

Figure 1. "Sprich nicht immer ... ." Arnold Schoenberg, I908-09. From Schoenberg's 15 Gedichte aus Das Buch der hängenden Gärten von Stefan George für Stimme und Klavier op. I 5. Copyright: Copyright I9I4, I94I by Universal Edition A.G. Vienna UE5338. License: CC-BY-NC-ND. 
However, these textual traits are not emphasized in Schoenberg's song; instead, it is one of the instances when he composes a kind of "musical prose," preventing symmetries and affording asymmetries. As Scott readily points out, the setting is totally at odds with all that which is associated with George's priestly readings within his circle. Indeed, the image of Schoenberg's textual distortion in scholarly comments on the George cycle are singled out by Scott (Harald Krebs speaks about "distortive inflections" whereas Karl Heinrich Ehrenfort points out a "breaking” through "barriers" ${ }^{27}$ ). From Scott's point of view Schoenberg misses all those joints that can appear (and then disappear) in the relation between music and text. Instead, Scott lapses into "non-musical" alternatives such as symbolism or even ciphers: the opening half-tone steps downward are seen as a returning motive that in its movements illustrate autumn leaves twisting and dancing in the wind. ${ }^{28}$

Yes, we have by then reached the process of musical semiosis. Scott is, however, not satisfied. The reason why is that all those "musical" and formal aspects that are of importance to George are almost wiped out by Schoenberg. The shaping forces of the song are only musical, whereas the intermedial relation is unmusical, according to Scott. And, of course, his own model for intermedial relations is not being activated by Schoenberg's setting.

\section{The Evasive Musical Meaning}

We should, however, not forget that Elleström's model covers all the relations that Scott highlights. The major difference is that

${ }^{27}$ Harald Krebs, "Three Versions of Schoenberg's Op. I 5 No. I 4: Obvious Differences and Hidden Similarities," Journal of the Arnold Schoenberg Institute 8:2 (I984): I3 I and Karl Heinrich Ehrenforth, Ausdruck und Form: Arnold Schönbergs Durchbruch zur Atonalität (Bonn: Bouvier, I963), 47 (my trans.): “'Durchbrechen' von 'Schranken.'” Scott quotes them in "Ich löse mich in tönen...," I07 and I I 0 respectively.

${ }_{28}$ Scott writes: "Hierein liegt das musikalische Hauptmerkmal von Schönbergs Ausdrucks- und Formideal der 'musikalischen' Prosa: Die Gestaltung der Gesangsstimme und die 'pointillistischen' Gesten der Klavierbegleitung sollen tonmalerische und tonsymbolische Chiffren für das sich im Gedicht entfaltende, herbstliche Bild konstituiren.” Scott, "Ich löse mich in tönen...," I09. 
Scott is only interested in the auditory aspects, since they have been downplayed by earlier theorists and since he has an investigation on the relation between George and the Second Vienna School in mind. One of the consequences is Scott's own lack of interest in musical semiosis. Elleström, on his part, tries to find a general model for intermediality, founded on a clarification of what a medium is. He avoids theoretical one-liners such as Marshall McLuhan's phrase that every medium is an "extension of man.” ${ }^{29}$ No, Elleström suggests a multi-facetted understanding, where any medium is said to be material, sensorial, spatiotemporal, and semiotic; a four-fold that he calls "modalities." ${ }^{\circ}$ Further, he adds two qualifying aspects, firstly the contextual qualifying aspect that puts the medium into a historical, cultural, and social context, and secondly the operational qualifying aspect that is given by its communicative and aesthetic characteristics. Such media that are dominated by their modal appearances are called "basic media" and those dominated by their qualifying aspects are called "qualified media." ${ }^{\text {I }}$

For me in this article, not discussing intermediality in general, but the intermedial relation between poem and the setting of that poem to music, it is of great importance that Elleström does not see a song as being constituted by the relation between text and music (a combination that Wolf would call "intracompositional intermediality"). As already mentioned, Elleström says that song is a qualified medium, constituted by two basic media, "auditory text" and "organized non-verbal sound." The combination and integration of these two basic media in a song happens through their common material interface, sound waves, and they are both fundamentally temporal and share spatial characteristics, too. However, the striking difference between these two basic media is according to Elleström that "the process of signification in auditory texts is mainly a question of decoding conventional signs, whereas the meaning of the organized non-verbal sound first and

\footnotetext{
29 Marshall McLuhan, Understanding Media: The Extensions of Man (Cambridge: MIT Press, I994), 24.

${ }^{\circ}$ Elleström, "The Modalities of Media," I 5.

${ }^{31}$ Elleström, "The Modalities of Media," 27.
} 
foremost is a result of interpreting the sounds in terms of resemblance and contiguity." ${ }_{22}$ Again, we see that the distinction between words and music is based on semiotic differences. But the song intended by Elleström is not any song, but a pop song. If his analysis up to this point can be said to be general for any songart songs, folksongs, Gregorian chant, singing incantations-the next qualifying step is said to be specific for pop songs:

The qualities of qualified media become even more qualified, so to speak, when aspects of genre are involved; a genre might therefore be called a sub-medium. Indeed, we usually deem that the lyrics produced by the singer are in themselves music, as is the sound produced by the mechanical and electronic instruments. The integration of the two basic media in a pop song is consequently in effect very deep, since the two media are more or less identical when it comes to three of the four modalities, and concerning the fourth modality, the semiotic, it is perfectly normal to integrate the symbolic and the iconic sign-processes in the interpretation of both literature and music. Texts are generally more symbolic and music is generally more iconic but the combination and integration of words and music stimulates the interpreter to find iconic aspects of the text and to realize the conventional facets of the music. ${ }^{33}$

There is much to comment on in this quotation. Firstly, the slightly surprising supposition that "we" take the lyrics sung by someone as music in itself, but one can presume that Ellerström intends the "musical" aspects of auditory texts. The fact is that the hovering status of language in a pop song lies behind the heated discussion on Bob Dylan as receiver of the Nobel Prize 2016: the texts by Dylan can of course be read in a book, but there is always something missing in silent reading of lyrics. A genuine kind of intermediality can be found here, since it is almost impossible to bring Dylan's voice into silence during the act of reading his texts once you have heard him singing a specific song. The assertion that auditory texts and organized non-verbal sound are more or less identical concerning the material, sensorial, and spatiotemporal modalities can be seen as an overstatement, but, in fact, we have

32 Elleström, "The Modalities of Media," 29.

33 Elleström, “The Modalities of Media," 29. 
in both cases to do with sound waves being perceived by the ear (if the music is loud, by the body, too) in temporal flow that takes place in a shared space. However, the difference between tone in non-musical auditory texts (such as spoken-word poetry) and tone in musical auditory texts, where that which Roger Scruton calls the musical "field of force" is active, must be taken into account. ${ }^{34}$ This field of force is dependent on musical phenomena such as the logic of melody and more or less obvious harmonic progression, both of them related to cultural factors, but yet vital to most if not all music cultures. There is a difference between a singing person and a person who speaks with a singing voice, with a number of shadings in between, such as Sprechgesang and rap, but in both cases the floating in between is seldom or never achieved.

Or do we find this opposition in the semiotic modality? Well, even if Elleström is totally right when saying that a song may impel the listener to find iconicity in the lyrics and conventional symbols in music, his reasoning it totally blank concerning musical phenomena such as mobility and spatiality, when these are not relating to a situation that might take place in reality. Music moves even if it does not move like something, and this movement may take place in a space that has nothing or very little to do with physical space. This is in fact the essential problem with any semiotic understanding of music. Music can obviously be an icon, reflecting the movement downward in a sigh, and that sign can also have a symbolic function when it is used as a standardized musical figure in an aria full of sorrow. Music can even be treated as an Peircean "index," 35 at least if we trust the major part of nonformalistic musical aesthetics that accepts that music is the language of feeling and that the composer expresses him- or herself in music. (I believe that this standard view must be accepted, even if most contemporary composers do other things

\footnotetext{
34 Scruton writes: "A tone is a sound which exists within a musical 'field of force.' This field of force is something that we hear, when hearing tones." Roger Scruton, The Aesthetics of Music (Oxford: Oxford University Press, I999), I7.

35 On the musical index, see, e.g., Vladimir Karbusicky, “The Index Sign in Music," in Semiotics of Music, ed. Eri Tarasti, special issue of Semiotica 66 (I986): 25-35.
} 
than expressing themselves and their affective state when they sit in front of their computer screen.) But most of the time, music does not stand for anything else, it does not function as a sign, it is nothing semiotic. There are even some problems with an interesting notion that Elleström has picked up in another context, namely music as an "empty sign," ${ }^{36}$ which can attract different meanings in different contexts, but which does not have a meaning of its own. Most often, music is no sign at all, be it empty or not.

However, a great advantage with Elleström's model is that it tends both to blur the borders between the media and to rely on a simple distinction between them. Let me explain this paradoxical statement. Saying that song, indeed, pop song, is a medium of its own, that is, a qualified medium, Elleström allows a song to be a song, that is, something that hovers in between linguistic and musical traits-where "linguistic" elements are of "musical" relevance and where music seems very close to language. He keeps at the same time the distinction between language and music as basic media. The problem is that he either overemphasizes music's iconicity, or disregards that important field of musical meaning, which has not to do with semiotics at all. Musical meaning? Well, that is the meaningful interplay between tones and rhythms, which cannot be articulated outside music. ${ }^{37}$ Meaning related to signification has to do with a relation where something stands for something else, whereas a tone or note often does not stand for anything, even if it has meaningful relations to other tones or notes. The understanding of the pronounced musical meaning has been the hallmark of the connoisseur (Kenner) in comparison with

${ }^{36}$ Concerning “empty signs," Elleström refers in his 2002 book on irony in the arts, Divine Madness, to Kevin Barry, who in his turn has observed it in eighteenth-century texts on musical aesthetics. In Divine Madness, Elleström discusses the problem with musical meaning with care, showing that he is well read in musical aesthetics. That makes it much harder to understand his later stance on music and semiosis. Cf. Lars Elleström, Divine Madness: On Interpreting Literature, Music, and the Visual Arts Ironically (Lewisburg: Bucknell University Press, 2002).

37 Cf. Matthias Vogel, "Nachvollzug und die Erfahrung musikalischen Sinns," in Musikalischer Sinn: Beiträge zu einer Philosophie der Musik, eds. Alexander Becker and Matthias Vogel (Frankfurt: Suhrkamp, 2007), 3 I 6. 
the amateur (Liebhaber) ever since the eighteenth century,,$^{38}$ and it is still working in silence in Theodor W. Adorno's typology of listeners and further on. ${ }^{39}$ The difference lies between someone who understands the logic of musical unfolding from the perspective of compositional technique and someone who only reacts upon this logic, be it in a very sensitive way, or even tries to understand the music as an expression of feeling with the consequence that the music becomes signs for inner states.

\section{Song as Event}

What takes place in a song, then? We cannot generalize this kind of event into a law, but at least we should be able to see that Goethe's famous praise of Carl Friedrich Zelter's settings, saying that they were identical with his poems, is a problematic way of describing a (successful) song. ${ }^{\circ}$ At the other extreme, we find Luigi Nono's string quartet Fragmente-Stille, An Diotima, which can be seen as a variant of Schoenberg's George settings in the last two movements of his Second String Quartet, with the obvious difference that Nono excludes vocal singing, but includes fragments of Hölderlin poems in the score to be "sung" in silence by the musicians ("The players should 'sing' them [the fragments] inwardly, in their autonomy")..$^{4}$

The relation between poem and music in art song has been open for debate ever since Socrates's demand in Plato's Republic

${ }^{8}$ Cf. the entry "Kenner" in Johann Georg Sulzer, Allgemeine Theorie der Schönen Künste, vol. 3 (Leipzig: Weidmannsche Buchhandlung, I793), $5-\mathrm{I} 4$.

39 Theodor W. Adorno, Einleitung in der Musiksoziologie, in Gesammelte Schriften, vol. I4 (Darmstadt: Wissenschaftliche Buchgesellschaft, I998).

$4 \circ$ In a letter to Zelter he writes: "Deine Kompositionen fühle ich sogleich mit meinen Liedern identisch, die Musik nimmt nur, wie ein einströmendes Gas, den Luftballon mit in die Höhe. Bei andern Komponisten muß ich erst aufmerken wie sie das Lied genommen, was sie daraus gemacht haben.” Johann Wolfgang von Goethe, Sämtliche Werke nach Epochen seines Schaffens: Münchner Ausgabe, vol. Io: I (Munich: Hanser, I999), 601 .

${ }^{4}$ Luigi Nono, Fragmente-Stille, An Diotima (Milan: Ricordi, I980), unpaginated (at the beginning of the score, italics in the original). 
that mode and rhythm must follow the words in a song ${ }^{42}$-if not further back in history. A contrast to the naïve attitude formulated by Goethe has been Suzanne Langer's and Edward T. Cone's suggestion that music appropriates the poem, ${ }^{43}$ instead of trying to translate or just accompany it. ${ }^{44}$ Pierre Boulez, reflecting upon his own practice when using texts in his compositions, draws this position to its extreme when he says that the formal traits of the poem might be of great importance for the construction of the work, whereas the poem is absent in the work. ${ }^{45}$ Langer's and Cone's amalgamation, steered by musical principles, is further put in doubt by Lawrence Kramer, who rather speaks about an agonic relation between words and music: "the song is a 'new creation' only because it is also a de-creation." ${ }^{46}$ If especially Cone would say that the composer uses a reading of the text, Kramer underscores that this reading then is both critical and performative. In his view, a struggle between word and music takes place in the art song, giving space to a very interesting question about intermediality concerning the original poem and the musical setting of it.

If we keep using the Schoenberg song as a litmus test for the different stances accounted for above, we can see that he in his composition has appropriated George's poem in an almost violent way. Nearly all rhythmical patterns are wiped out, the assonances and rhymes do not have a structuring function, and the text seems to be reduced to prose. It is through a thorough reconstruction of the circumstances around George's text that we can see how far

${ }^{22}$ Cf. Plato, Republic, Books I-5 (Cambridge: Harvard University Press, 20I3), 270.

43 Cf. Susanne K. Langer, Feeling and Form: A Theory of Art developed from Philosophy in a New Key (London: Routledge and Kegan, I953), I 53; Edward T. Cone, The Composer's Voice (Berkeley and Los Angeles: University of California Press, I974), I9.

${ }^{44}$ Here and in the following comments on Pierre Boulez and Lawrence Kramer, I am indebted to Håvard Enge's introduction to the dissertation Music Reading Poetry: Hans Zender's Musical Reception of Hölderlin (PhD diss., University of Oslo, 2010), 9-27.

45 Pierre Boulez, "Poésie - centre et absence - musique," in Points de repère, Tome I: Imaginer (Paris: Christian Bourgois Éditeur, I995).

${ }^{46}$ Lawrence Kramer, Music and Poetry: The Nineteenth Century and After (Berkeley and Los Angeles: California University Press, I984), I 27. 
the musically performed words have been taken from the imagined readings of the poem in the solemn meetings of the George circle.

However, we do find an element that seems to have almost such qualities that it can be ranked as an instance of transmediality, namely the tone. In another context, I have developed the characteristics of this both fugitive and pervasive phenomenon in George's lyrical output. ${ }^{47}$ It has been witnessed and discussed by sensitive readers such as Friedrich Gundolf and Hans-Georg Gadamer, ${ }^{48}$ but it was also decisive to Schoenberg in his choice of George during the period when he released himself from tonality and tried to find something that could organize a composition without the tonal reference. ${ }^{49}$ Being freed from concrete materialization in rhythm and sound, being an "intonation" of the words rather than a melodic contour, its shortest formulation can be seen in a quotation from one of George's own poems: it is the "droning of the sacred voice" (Dröhnen der heiligen Stimme)..5 Gundolf quotes these words by George in a context where he discusses the difference between the young poet and the mature one, where the young poet is said to not proclaim a world with his word, whereas the mature poet installs such a world. ${ }^{\text {I }}$

When trying to elucidate his concept of "tone," Gundolf rather says what it is not, and not what it is. When absent, even the most sublime words seem to be empty; when present, an inauguration takes place. According to Gundolf, George has a tone, as well as Shakespeare, and, surprisingly, Napoleon, all of them persons who, in different media, have installed worlds..$^{52}$ If we try

47 Erik Wallrup, "From Mood to Tone: On Schoenberg and Musical Worlds," Danish Musicology Online, special edition, I 7 th Nordic Musicological Congress (2016): I23-I44.

${ }^{8}$ Cf. Friedrich Gundolf, George, 3rd ed. (Berlin: Bondi, I930) and the following essays by Hans Georg Gadamer: "Der Dichter Stefan George" and "Hölderlin and George," in Gesammelte Werke, vol. 9, Tübingen: Mohr Siebeck, I993.

49 Cf. the following texts by Arnold Schoenberg: "Composition with Twelve Tones (I)," in Style and Idea, and "The Relationship to the Text."

$5 \circ$ Stefan George, "Entrückung," in Werke, 293.

${ }^{5}$ Gundolf, George, 6I.

52 Gundolf, George, 6I. 
to find out what he actually means, then the answer must be that "tone" is not something, it is not a thing, yet it can be traced in the order of the poem. This world is not set up by the tone, but it is "in tone," according to an intonation. Neither tone, nor world, can be made into objects for an investigation, since they are not objects: the world is that which gathers things together, not being a thing itself, and the gathering is made in accordance with the tone. Gadamer, in his turn, refers to George's tone as "the melodic substance of Gregorian chant," ${ }_{53}$ and that gives another clue: the intonation that takes place can be likened with the intonation in plainchant, namely an initial melodic phrase sung by the priest before the other voices joins the singing-a defining and stabilizing motion.

Here we find a new turn of the metaphor of a contract. A successful artwork installs a world, and this world is primordial in relation to the elements that can be found within it. If the contract was broken, then a new one is written, establishing new kinds of relations between the words and the tones. This is also what happens in Schoenberg's song: the establishment of a world, now not made of words only, but a new order for all relations between words and tones as well as for words and words and tones and tones.

What clearly is a very meagre material for generalizations-a song with a duration of 40 seconds—cannot be seen as anything else than a hint. But what this hint says is that we must start with concrete works of art if we want to understand the way in which basic media such as "auditory text" and "organized non-verbal sound" are combined in a "qualified medium" as an art song. The song is to be taken as an event. So I said from the start, but then without elaborating the meaning of the word. Being a primordial event, the song cannot be taken as an object, which can be decomposed into its simpler, constituent elements. Instead, it is something that happens through opening up a world, which allows the listener to be a part of it, exposing him or her for a changed order. It invites the listener to stand out in another sphere than the customary one. Now, the point has been reached where

53 Gadamer, “Der Dichter Stefan George," 222. 
it is possible to insert the intermedial notions already put in play: the event lets a world take place, a world that lets the signs be signs (be they symbolic, iconic, or indexical) and determines the relations between the basic media that are parts of the qualified medium. Here, the intermedial investigation should be directed at elucidating the differences and similarities between the worlds of the poem and the song, both of them emerging as events which take place under specific historical and aesthetic circumstances.

Every time the song is sung (or, for the Kenner, read vividly), the world emerges, at least as long as it achieves an impetus that displaces the expectations of the listener. Schoenberg's music has still that capacity, strangely enough. How can it then be that the song sounds so different, sung by different singers (both male and female), and played by different pianists? The solemn melancholia is obvious when Christian Gerhaher sings with Gerold Huber at the piano. Brigitte Fassbaender sounds more like a singer who has escaped from Pierrot Lunaire, when she, together with the pianist Aribert Reimann, makes a theatrical interpretation. Glenn Gould's dropping, capricious piano playing and Helen Vanni's operatic mezzo-soprano emerges in one stroke, a contrast that only can be fathomed with a reflective act after its appearance. ${ }^{54}$ Yet, all these different concretizations give a hint of the tone of the poem, and this tone should not be confounded with the actual voice in the performance. The tone of the poem is an in-between, a potentiality. The successful interpretation (all those mentioned here are successful, but in very different ways) keeps something of the tone, though not making it manifest: it is an affecting absence.

In three steps, I have turned from a quite common notion of the language-music interrelations in intermedial studies grounded upon semiotics (afforded by Werner Wolf and Lars Elleström), over an auditory model (developed by Calvin Scott), arriving at an understanding of the relation between a poem and a song set

54 The following recordings of the song are referred to: Christian Gerhaher and Gerold Huber, Sony Classical 88691935432, 20I2; Brigitte Fassbaender and Aribert Reimann, His Master's Voice IC 067 I 46685 I, I983; Helen Vanni and Glenn Gould, Columbia Masterworks, M2S 736, I966. 
to that same poem as one between two different emerging worlds. That which has been suggested does not gainsay the fact that songs and indeed music alone may communicate something semiotically, or that music may have formal aspects that cannot be reconciled with linguistic meaning. Instead, a more primordial point is reached where a song (here exemplified with one song only, by Arnold Schoenberg, leaving much to be done before the position taken can be said to be well grounded) is grasped as an event where a world is opened up. This world installs the possible relations between words and words, tones and tones, as well as words and tones; it allows signs to be signs, and it determines the basic media as parts of the qualified medium that a song is. In this way, we can begin to investigate how this world of a song is related to the world of the poem to which music has been set. The words in the song and those in the poem may be identical, but they are not the same. Yet, the song might preserve something of the tone of the poet, that extremely elusive phenomenon that in an intermedial investigation can be said to be transmedial.

\section{References}

Adorno, Theodor W. Einleitung in der Musiksoziologie, in Gesammelte Schriften, vol. I4. Darmstadt: Wissenschaftliche Buchgesellschaft, I998.

Arvidson, Mats. "Music and Musicology in the Light of Intermediality and Intermedial Studies." STM-Online I 5 (2012).

Boulez, Pierre. "Poésie - centre et absence - musique.” In Points de repère, Tome I: Imaginer. Paris: Christian Bourgois Éditeur, I995.

Brown, Calvin S. Music and Literature: A Comparison of the Arts. Athens: The University of Georgia Press, I949.

Bruhn, Jørgen. "Intermedialitet: Framtidens humanistiska disciplin?” Tidskrift för litteraturvetenskap 38:I (2008): 2I-38.

Cone, Edward T. The Composer's Voice. Berkeley and Los Angeles: University of California Press, I974.

Dahlhaus, Carl. “Musikalische Prosa.” In Gesammelte Schriften, vol. 8, 20. Jahrhundert, 36I-374. Laaber: Laaber, 2005. 
Ehrenforth, Karl Heinrich. Ausdruck und Form: Arnold Schönbergs Durchbruch zur Atonalität. Bonn: Bouvier, I963.

Elleström, Lars. Divine Madness: On Interpreting Literature, Music, and the Visual Arts Ironically. Lewisburg: Bucknell University Press, 2002.

Elleström, Lars. "Iconicity as Meaning Miming Meaning and Meaning Miming Form.” In Signergy, edited by Jac Conradie et al., 73-100. Philadelphia: John Benjamins, 20 Iо.

Elleström,Lars. “The Modalities of Media: A Model for Understanding Intermedial Relations." In Media Borders, Multimodality and Intermediality, edited by Lars Elleström, I I-48. London: Palgrave Macmillan, 20I0.

Enge, Håvard. Music Reading Poetry: Hans Zender's Musical Reception of Hölderlin. PhD diss., Department of Musicology, University of Oslo, 2010.

Gadamer, Hans Georg. "Der Dichter Stefan George.” In Gesammelte Werke, vol. 9, 2 I I-228. Tübingen: Mohr Siebeck, I993.

Gadamer, Hans Georg. "Hölderlin and George." In Gesammelte Werke, vol. 9, 229-244. Tübingen: Mohr Siebeck, I993.

George, Stefan. Werke: Ausgabe in zwei Bänden. Stuttgart: KlettCotta, I984.

Goethe, Johann Wolfgang von. Sämtliche Werke nach Epochen seines Schaffens: Münchner Ausgabe, vol. Iо:I, 60I. Munich: Hanser, I999.

Gundolf, Friedrich. George. 3 rd ed. Berlin: Bondi, I930.

Hansen-Löve, Aage. "Intermedialität und Intertextualität: Probleme der Korrelation von Wort- und Bildkonst - Am Beispiel der russischen Moderne." In Dialog der Texte: Hamburger Kolloquium zur Intertextualität, Wiener slawistischer Almanach, Sonderband I I, edited by Wolf Schmid and Wolf-Dieter Stempel, 29I-360. Wien: Gesellschaft zur Förderung slawistischer Studien, I983.

Hofmannsthal, Hugo von. "Ein Brief." In Gesammelte Werke: Erzählungen, Erfundene Gespräche und Briefe, Reisen, 46I-472. Frankfurt: Fischer, I979. 
Karbusicky, Vladimir. "The Index Sign in Music.” In Semiotics of Music, special issue of Semiotica 66 (I986): 23-35.

Kramer, Lawrence. Music and Poetry: The Nineteenth Century and After. Berkeley and Los Angeles: California University Press, I984.

Krebs, Harald. "Three Versions of Schoenberg's Op. I 5 No. I4: Obvious Differences and Hidden Similarities." Journal of the Arnold Schoenberg Institute 8:2 (I984): I3 I-I40.

Langer, Susanne K. Feeling and Form: A Theory of Art developed from Philosophy in a New Key. London: Routledge and Kegan, I953.

Luhmann, Niklas. Die Kunst der Gesellschaft. Frankfurt: Suhrkamp, I995.

Luhmann, Niklas. Die Gesellschaft der Gesellschaft. Frankfurt: Suhrkamp, I997.

Maeder, Costantino. “Opera, Oratorio, and Iconic Strategies.” In Iconic Investigations, edited by Lars Elleström, Olga Fischer, and Christina Ljungberg, 275-289. Philadelphia: John Benjamins, 20I3.

McLuhan, Marshall. Understanding Media: The Extensions of Man. Cambridge: MIT Press, I994.

Plato, Republic, Books I-5. Cambridge: Harvard University Press, $20{ }_{3} 3$.

Schoenberg, Arnold. “The Relationship to the Text." In Style and Idea, I4 I-I 45. Berkeley: University of California Press, I984.

Schoenberg, Arnold. “Composition with Twelve Tones (I).” In Style and Idea, 2 I4-245. Berkeley: University of California Press, I984.

Schoenberg, Arnold. "Brahms the Progressive." In Style and Idea, 398-44 I. Berkeley: University of California Press, I984.

Scott, Calvin. "Ich löse mich in tönen...": Zur Intermedialität bei Stefan George un der Zweiten Wiener Schule. Berlin: Frank \& Timme, 2007.

Scruton, Roger. The Aesthetics of Music. Oxford: Oxford University Press, I999.

Steiner, George. Real Presences: Is There Anything in What We Say. London: Faber and Faber, I989. 
Sulzer, Johann Georg. "Kenner.” In Allgemeine Theorie der Schönen Künste, vol. 3, 5-I4. Leipzig: Weidmannsche Buchhandlung, I793.

Wallrup, Erik. "From Mood to Tone: On Schoenberg and Musical Worlds." Danish Musicology Online, special edition, I 7 th Nordic Musicological Congress (2016): I23-I44.

Vogel, Matthias. "Nachvollzug und die Erfahrung musikalischen Sinns." In Musikalischer Sinn: Beiträge zu einer Philosophie der Musik, edited by Alexander Becker and Matthias Vogel, 3 I4-368. Frankfurt: Suhrkamp, 2007.

Wolf, Werner. "Intermedialität als neues Paradigma der Literaturwissenschaft? Plädoyer für eine literaturzentrierte Erforschung von Grenzüberschreitungen zwischen Wortkunst und anderen Medien am Beispiel von Virginia Woolfs 'The String Quartet'." Arbeiten aus Anglistik und Amerikanistik 2I:I (I996): 85-I I6.

Wolf, Werner. The Musicalization of Fiction: A Study in the Theory and History of Intermediality. Amsterdam: Rodopi, I999.

Wolf, Werner. “Intermediality Revisited.” In Essays in Honor of Steven Paul Scher on Cultural Identity and the Musical Stage, Word and Music Studies, edited by Suzanne M. Lodato, Suzanne Aspden, and Walter Bernhart, I3-34. Amsterdam: Rodopi, 2002.

\section{Musical Works}

Nono, Luigi. Fragmente - Stille, An Diotima. Milan: Ricordi, I980.

Schoenberg, Arnold. I5 Gedichte aus Das Buch der hängenden Gärten von Stefan George. Wien: Universal Edition, I908-09.

\section{Recordings}

Schoenberg, Arnold. Das Buch der hängenden Gärten. Helen Vanni (song) and Glenn Gould (piano). Columbia Masterworks, M2S 736, 1966.

Schoenberg, Arnold. Das Buch der hängenden Gärten. Brigitte Fassbaender (song) and Aribert Reimann piano. His Master's Voice IC 067 I4668 5 I, I983.

Schoenberg,Arnold.Das Buch der hängenden Gärten. Christian Gerhaher (song) and Gerold Huber (piano). Sony Classical 8869I93 5432, 20 I 2. 